\title{
The Effectiveness of Yobikake-outou No Hyougen Learning through the Grammar Translation Method for Students of Monarch Bali Dalung
}

\author{
Ni Putu Eka Yani ${ }^{1}$, I Wayan Simpen ${ }^{2}$, Ketut Widya Purnawati ${ }^{3}$ \\ ekayani0110@gmail.com \\ Udayana University, Denpasar 80114, Indonesia
}

\begin{abstract}
This study aimed in analyzing (1) the Japanese language skills of Monarch Bali Dalung students, especially in learning yobikake-outou no hyogen before the Grammar Translation Method (GTM) is applied; (2) the Japanese language skills of Monarch Bali Dalung students, especially learning yobikake-outou no hyougen after the Grammar Translation Method (GTM) is applied and its effect on students; (3) the factors that influence the application of the Grammar Translation Method (GTM) to Monarch Bali Dalung students in learning Japanese, especially learning yobikake-outou no hyougen. This research is an experimental research with quantitative and qualitative approaches. The experimental research design used in this study is a quasiexperimental design. The theories used in this research are language learning theory, pragmatic theory, and sociocultural theory. The results showed that the Grammar Translation Method (GTM) method can improve Japanese language learning outcomes for Monarch Bali Dalung DMM students, especially in learning yobikake outou no hyougen. This can be seen from the average value of student learning outcomes that have increased, namely the average value of the initial test in the experimental group was 21.50 and the final test score is 71.10. The standard deviation of the initial test was 11,859 and the final test was 12,339 , while in the control group the initial test score was 21.90 and the final test score was 50.70. The standard deviation of the initial test was 11,923 and the final test was 12,522. The hypothesis tested by using t-test. Based on the effective category obtained according to the average value (mean) of N-Gain, that the GTM method in learning yobikake outou no hyougen was said to be 'quite effective'. The factors that influence the implementation of the Grammar Translation Method (GTM) were external factors and internal factors. External factors were in the form of unattractive applications, while internal factors are student motivation.
\end{abstract}

Published by IJRP.ORG. Selection and/or peer-review under responsibility of International Journal of Research Publications (IJRP.ORG)

Keywords: GTM, Yobikake otuou no hygen Learning, Japanese Language Skil

\section{Introduction}

Language is a communication tool that is used to interact both individually and in groups. Each language is unique, both written and spoken. This is what attracts everyone to learn a foreign language. Nowadays, the use of foreign languages, in particular, Japanese is increasing. Therefore, teaching the basics of the Japanese 
language must be done properly as a provision for students to master the Japanese language both spoken and written. When learning Japanese, Japanese learners learn to master the four language skills ranging from listening 聞く技能 (kiku ginou), speaking 話す技能 (hanasu ginou), reading 読む技能 (yomu ginou), and writing 書く技能 (kaku ginou). In addition to the four skills above, it is very important for students to know the use of language that is appropriate and in context. This is because in Japanese, there are several expressions that have the same meaning but are used in different contexts and situations.

The Monarch Bali Dalung Job Training Institute (LPK) is one of the institutions that teach Japanese as an additional language. Therefore, it emphasizes conversation (kaiwa). This is because, in the field of tourism, it is required to be able to communicate well using foreign languages. However, the lack of understanding of the expression (hyougen) that is appropriate to the context and situation, especially the use of yobikake-outou no hyougen is a problem that needs attention. Therefore, the context in question is the speaker and opponent of speech, place, time, and the assumptions involved in the act of expressing the action. Yobikake no hyogen is an expression used by speakers when conveying something to get the other person's attention. In addition, outou no hyogen is an expression used when answering a question or responding to something that is used as a topic of conversation by the other person (Ogawa, 1995: 193-214). Although this seems very simple, it seems impolite if there are inappropriate contexts and situations.

As the phenomenon found, the use of yobikake-outou no hyogen for Monarch Bali Dalung students was still very limited. For example, responding to the conversation of the interlocutor, students only used the expressions hi and iie. Even though there are still many expressions that they can use. Problems were also often found when mentioning the name of the interlocutor who has a higher status. Students often used the term kun, or chan, so that it seems impolite. The expression kun or chan should only be used to call the name of a familiar friend. In addition, the expression wakarimashita or kashikomarimashita even though it had the same meaning, namely "to understand or understanding the meaning the interlocutor" but the context of its use is different. Students still often use these terms incorrectly.

In addition, Sutedi (2011: 46-47) reveals that a common obstacle in learning Japanese is the tendency of students who only know part of the entire meaning of a word, while the other meanings intended by speakers often cannot be digested because they don't know it. In other words, many Japanese expressions have the same meaning but are used in different contexts and situations. In addition, the selection of methods that were not appropriate to be applied by teachers or instructors is one factor in the lack of students' understanding. Therefore, the researchers tried to apply the Grammar Translation Method (GTM) in teaching the yobikake outou no hyogen. Thus, researcher was interested in applying the GTM method to the yobikake-outou no hyougen learning process for students of the Diploma II Program in the Food and Beverage Division (DMM). Hence, this study aimed at analyzing Japanese language skills of Monarch Bali Dalung students, especially in learning yobikake-outou no hyogen before and after the Grammar Translation Method (GTM) was applied and the factors that influence the application of the Grammar Translation Method (GTM) to Monarch Bali Dalung students in learning yobikake-outou no hyougen.

\section{Theoretical Framework}

\subsection{Language Learning Theory}

Learning refers to conscious knowledge of language and knowledge of language rules. Learners know the rules, master the grammar, and can talk about them. Formal knowledge of the language or the learning process can explicitly be associated with the term learning. Language learning involves at least three disciplines, namely linguistics, psychology, and pedagogy. Linguistics provides information about language in general. Psychology describes how people learn things. Pedagogy (educational science) allows us to mix all the information from (a) and (b) into one approach, method, and technique that is appropriate and used in order to facilitate the language learning process, especially in learning foreign languages (Wicaksono, 2016:1). 
In this case, language learning is generally based on four key concepts: language, learning, teaching, and context. (1) language learning requires context about the nature of language. (2) language learning requires views and insights about the learner and the nature of language learning, (3) language learning implies views about language learning and teaching. (4) language learning occurs in certain contexts. Language, learning, and teaching must always be viewed from a context and background (Wicaksono: 2016:1). The effectiveness of the learning process is closely related to the ways, efforts, techniques, and strategies used in achieving goals optimally, precisely, and quickly. To be able to determine the level of success of a method used in learning, effectiveness is a very important factor in learning, because effectiveness, in general, can determine to what extent a predetermined goal is achieved.

Moreover, learning effectiveness is the level of success that can be achieved from the application of a learning method, which is measured through the learning outcomes of students after the implementation of the method. If student learning outcomes have increased after the implementation of the learning method, it is said that the method is effective, otherwise, if student learning outcomes have decreased or even settled (no warning) then the method is said to be ineffective. There are various factors that influence the effectiveness of a learning process, including teaching staff/teachers, student factors, learning materials, media, and learning methods. However, in this study, researchers only focused on the effectiveness of using the Grammar Translation Method (GTM) learning method in learning Japanese, especially learning yobikake outou no hyoigen.

\subsection{Grammar Translation Method}

Literally, the method means the regular way used to carry out a job in order to achieve the desired, systematic way of working to facilitate the implementation of an activity in order to achieve the specified goals. Grammar Translation Method (GTM) was first developed in mainland Europe around the 17th century until the mid-20th century. This method was originally used to study classical languages such as Greek and Latin and to translate various documents, books, and other writings. The main activity of the teacher in the GTM teaching and learning process is to provide grammatical explanations and translations that are deemed necessary. First, the teacher provides an understanding of sentence structure and grammatical rules.

This method can help learners to better understand the language they are learning by analyzing the grammar and translation of the target language. This allows students to explore reading material. Kimura Muneo (1992: 48) says the characteristics of GTM are 1) Emphasis on a variety of writing 2) Very suitable for objects that have a high intellectual level, 3) Teachers need to have knowledge of the language being taught, but do not need to have high-level language teaching techniques. The advantage of this method is that it can be used for a large number of students at the same time, very useful for the absorption of foreign cultures.

Regarding translation, a translator must have a clear translation method, namely doing the translation according to what has been planned. Of course, the choice of a method is accompanied by careful considerations regarding the target reader, the type of text, the wishes and intentions of the author of the text, and the purpose of translating the text. This method strongly adheres to mental discipline and intellectual development.

\subsection{Theory of Pragmatic}

When someone hears an utterance, usually someone not only understands the meaning of the words but also the meaning of the utterance contained in the utterance. To understand this meaning, speakers need to pay attention to the existing context so that communication runs smoothly and there are no misunderstandings. In this regard, we need a field of science that studies speech with its context, namely pragmatics. Pragmatic theory refers to the pragmatic theory proposed by experts including Levinson (1983: 9) explaining pragmatics as the study of language which studies the relation of language to its context. 
Meanwhile, Leech (1993: 8) defines pragmatics as the study of meaning in relation to speech situations which include the elements of the greeter and who is addressed, context, purpose, illocutionary acts, and situations. Therefore, the pragmatic approach in language learning cannot be separated from the concept that connects the use of language with the context of the speech situation.

Yule (1996:3) suggests that pragmatics is the study of meaning conveyed by speakers and interpreted by listeners (or readers). Furthermore, the definition of pragmatics (goyouron) according to the Japanese pragmatist Koizumi (1993: 282):

\section{語用論は文の意味、これが使用される場面との間の反応関係を解明しようともくろんでいる。}

Goyouron wa bun no imi to, kore ga shiyou sareru bamen to no ma no hannou kankei wo kaimei shiyou to mokurondeiru

"Pragmatics intends to explain the reciprocal relationship between the meaning of the sentence and the situation used"

Based on some of the opinions above, it can be said that the study of pragmatics is more related to the analysis of utterances than the separate meanings of words and phrases used in speech. Pragmatics examines the form of interpretation of either the speaker or the addressee in a conversational context. To determine the meaning of an act of communication, various considerations are needed. The elements that are taken into consideration are the speaker, the speaker, where, when, and under what circumstances the act of communication took place. Because pragmatics cannot be separated from speech acts and the context of speech so that communication can run smoothly. It should be understood that good language skills lie not only in the suitability of grammatical rules but also in pragmatic rules.

In relation to this research, the use of Yobikake-outou no hyogen is in accordance with the context and situation. As for the context in question namely (1) the personal context, namely the position of the speaker, the age of the speaker and the age of the interlocutor, the socio-economic background of the speaker and the interlocutor; (2) the context of place and formal context, for example, used in a restaurant, company, both in formal and informal situations; (3) the context of the goal, namely the intention that the speaker wants to convey to the interlocutor through the expressions used.

\subsection{Sociocultural Theory}

The expressions yobikake outo no hyougen in their use pay close attention to the relationship between the interlocutor and the speaker which is closely related to social aspects prevailing in society. Sociocultural theory is used to analyze the use of expressions in Japanese, in this particular case the use of yobikake outou no hyogen. There are three variables that affect the situation of speech acts, namely strength or power $(\mathrm{P})$, distance or distance (D), and the level of weighting or rank of imposition (R) according to Brown and Levinson, (1983). Prefers to three types of speaker and interlocutor relations in the type of social status. The three relationships refer to higher, equal, and lower listener status. D refers to familiarity (close relationships and distant relationships) that can affect the language and attitudes of both the speaker and the interlocutor. $\mathrm{R}$ refers to the weight on the interlocutor and which contains two large and small scales.

The use of yobikake outou no hyogen is closely related to strength (P) and distance (D). The existence of different levels of social status in Japanese society causes the use of yobikake outou no hyogen to be adapted to the right context and situation in order to create the impression of politeness. Regarding the factors that influence the use of polite language in the Japanese society system, namely familiarity, age, social relations, social status, gender, group membership, and situation. 


\section{Methods}

The research design was a quantitative and qualitative research. The qualitative method in this study was in the form of words and sentences that were used to emphasize the linguistic aspects as a research tool, while the quantitative method in this study was in the form of tables, numbers used to determine the percentage of effectiveness in this study. This study used a research design in the form of a pretest and posttest control group, not randomly. In this design, there were experimental groups and control groups that were not chosen randomly. This model used a pretest before giving treatment, after being given treatment, action was given a posttest to find out the consequences of the treatment that has been given, so that the effectiveness of the experimental method could be known with certainty.

The type of experimental research used in this research was quasi-experimental (Quasi-Experimental Design). Quasi-experimental is used when not all situations can be fully controlled. This experimental study consisted of two classes, namely the experimental class and the control class. In each class, the sample was given a different treatment. The first class as the experimental class was given treatment by applying the Grammar Translation Method. The second class as the control class was given the application of learning that did not apply the method.

\section{Result and discussion}

\subsection{Analysis of Pre-action Quantitative}

The results of observations made showed the lack of attractiveness of the learning methods applied by the instructors which resulted in teaching and learning activities being less effective. Most of the students did not understand the instructor's explanation. The explanation that the instructor gave was less detailed due to the absence of references used by the instructor in compiling the chronology of the story. In this case, the use of expressions contained in Japanese conversations that students learn. As a result, when the instructor asked again related to the learning material that had been explained by the students, many students were confused and asked their next-door friend who they thought understood. In the pre-action stage, the instructor just stands in front of the class while explaining the material. It seems that due to the less detailed explanation of the material, many students do not pay too much attention to the instructor's explanation. This is evidenced by the KKM that has not been achieved for all DMM 2 and DMM 4 students.

A. Experimental Class

Based on the data from the pretest results of the experimental class to 20 students, the data obtained from the pretest scores of the experimental class students had the highest score of 40 and the lowest score of 0 . Moreover, From the results of the frequency distribution of the experimental class pretest results, a histogram of the experimental class pretest values can be made as shown in Figure 1.

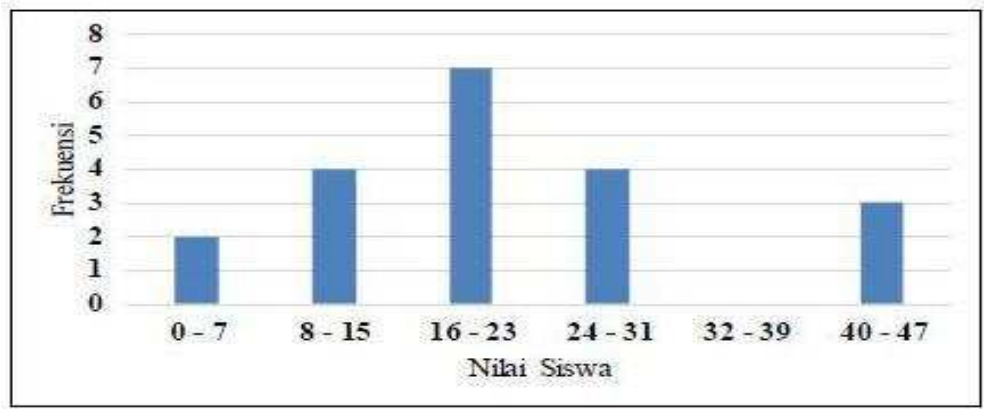

Figure 1. Histogram of Experimental Class Pretest Score 
Figure 1 shows that most students have a score interval of $16-23$ and at least students have a value 100 interval of 32 - 39. Furthermore, to determine the category of students' abilities from the results of the experimental class pretest as it is presented in table below.

Table 1. Category of Experimental Class Students' Ability Based on Pretest Results (Pre-Action)

\begin{tabular}{|c|c|c|c|}
\hline Value range & Category & Frequency & $\%$ \\
\hline $85-100$ & Very Good & 0 & 0 \\
\hline $70-84$ & Good & 0 & 0 \\
\hline $55-69$ & Fair & 0 & 0 \\
\hline $45-54$ & Poor & 0 & 0 \\
\hline $0-44$ & Very Poor & 20 & 100 \\
\hline Total & & 20 & 100 \\
\hline
\end{tabular}

In the table above, it can be seen that based on the results of the pretest in the experimental class, all students have initial abilities in the very poor category.

B. Control Class

Based on the data from the control class pretest results to 20 students, the data obtained from the control class students' pretest scores had the highest score of 40 and the lowest score of 0 . Moreover, from the results of the frequency distribution of the control class pretest results, a histogram of the control class pretest values can be made as shown in Figure 2.

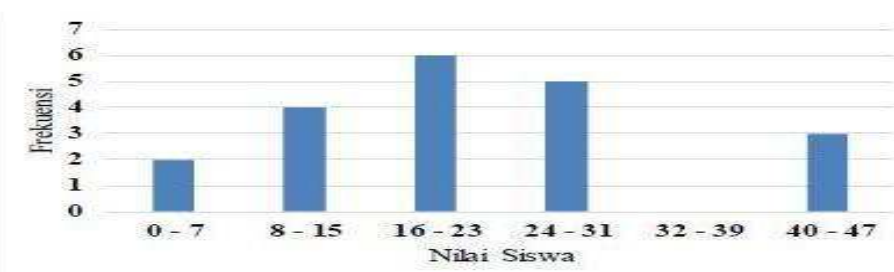

Figure 2. Histogram of Control Class Pretest Score

Figure 2 shows that most students have a score interval of 16-23 and the least students have a value interval of 32-39. Furthermore, to determine the category of students' abilities from the results of the control class pretest, it can be seen in Table 10 .

Table 2. Category of Control Class Students' Ability Based on Pretest Results (Pre-Action)

\begin{tabular}{|c|c|c|c|}
\hline Value range & Category & Frequency & $\%$ \\
\hline $85-100$ & Very Good & 0 & 0 \\
\hline $70-84$ & Good & 0 & 0 \\
\hline $55-69$ & Fair & 0 & 0 \\
\hline $45-54$ & Poor & 0 & 0 \\
\hline $0-44$ & Very Poor & 20 & 100 \\
\hline Total & & 20 & 100 \\
\hline
\end{tabular}

In Table 10, it can be seen that based on the results of the pretest in the control class, all students have initial abilities in the very poor category. 
Based on the quantitative data described above, it could be observed that in general, the average ability of students in the use of yobikake outou no hyogen in the pretest that has been tested, most of the students' errors are in the use of expressions according to the context of the interlocutor. Based on the result of questionnaire per-action that presented below based on the statements listed in the questionnaire.

1. "I am happy to follow the Japanese expression lesson with the lecture and question and answer method". There were 11 students agreed with the statement, 4 students had doubts about the statement and 5 students did not agree with the statement.

2. "The lecture method made me more interested in learning Japanese, especially learning about expressions", 8 students agreed with the statement, 10 students had doubts about the statement and 2 people disagreed with the statement.

3. Furthermore, the third statement was "The lecture method made it easier for me to understand the use of yobikake outou no hyogen", 5 students agreed with the statement, 8 students were hesitant with the statement and 7 students disagreed with the statement.

4. The last is the fourth statement "After following this learning with the implementation of the lecture method I feel the class atmosphere is very pleasant and not boring", 5 students agree with the statement, 10 students are hesitant with the statement and 5 students agree with the statement.

\subsection{Analysis of Post-action Quantitative}

The improvement of students' scores shown after applying the GTM method in the treatment class. After the final test was held in the experimental class, the highest score in this class was 90 and the lowest score was 50. The number of students in the experimental class who received an excellent predicate was 3 people, 4 students received a good predicate, 10 students received an adequate predicate, and 3 students received a poor predicate. As for giving the final test to the control class, the highest score was 70 and the lowest score was 30. There was no students in the control class who got very good scores, there was 3 students who got good marks, there were 4 students who got good marks enough, and there were 13 students who scored less.

A. Experimental Class

Based on the data from the posttest results of the experimental class to 20 students, the data obtained from the posttest results of the experimental class students had the highest score of 90 and the lowest score of 50 . Moreover, from the results of the frequency distribution of the experimental class posttest results, a histogram of the experimental class posttest values can be made as shown in Figure 3.

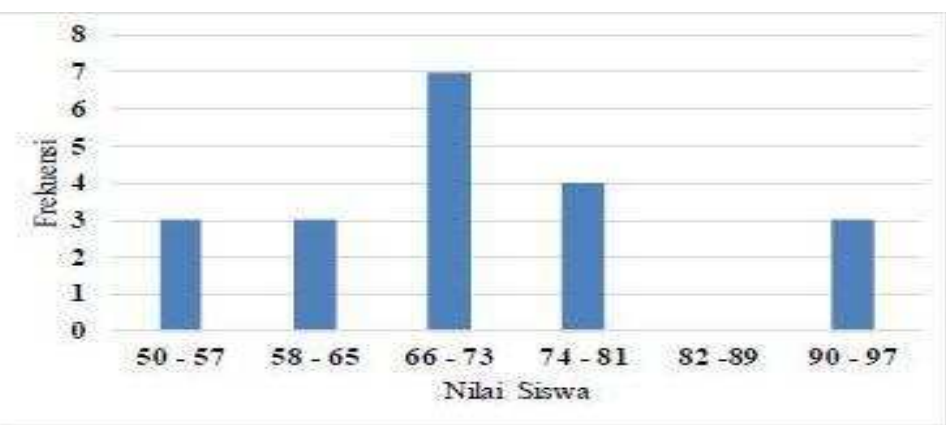

Figure 3. Histogram of Control Class post-test Score 
In figure 3, the results showed that most students had an interval of 66-73 and at least students had an interval of 82-89. Furthermore, to determine the category of students' abilities from the results of the posttest experimental class, it can be seen in the following table.

Table 3. Category of Experimental Class Students' Ability Based on Post-test Results

\begin{tabular}{|c|c|c|c|}
\hline Value range & Category & Frequency & $\%$ \\
\hline $85-100$ & Very Good & 3 & 15 \\
\hline $70-84$ & Good & 11 & 55 \\
\hline $55-69$ & Fair & 6 & 30 \\
\hline $45-54$ & Poor & 0 & 0 \\
\hline $0-44$ & Very Poor & 0 & 0 \\
\hline Total & & 20 & 100 \\
\hline
\end{tabular}

The table above showed that based on the posttest results in the experimental class that there were $3(15 \%)$ students had abilities with very good categories, 11 (55\%) of students had abilities with good categories, 6 $(30 \%)$ of students had abilities with sufficient categories and There were no students who had the ability in the category of less and very less.

\section{B. Control Class}

Based on the data from the control class posttest results to 20 students, the data obtained from the posttest results with the highest score of 70 and the lowest score of 30. From the results of the frequency distribution of the control class posttest results, a histogram of the control class posttest values can be made as shown in Figure 4.

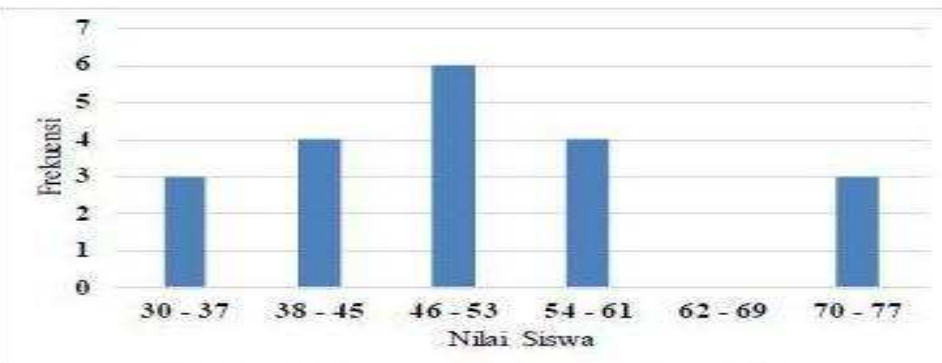

Figure 4. Histogram of Experimental Class post-test Score

The histogram above shows that most students have a score interval of 46-53 and the least number of students have an interval of 62-69. Furthermore, to determine the category of students' abilities from the results of the control class posttest, it can be seen in the following table.

Table 4. Category of Control Class Students' Ability Based on Post-test Results

\begin{tabular}{|c|c|c|c|}
\hline Value range & Category & Frequency & $\%$ \\
\hline $85-100$ & Very Good & 0 & \\
\hline $70-84$ & Good & 3 & 15 \\
\hline $55-69$ & Fair & 4 & 20 \\
\hline $45-54$ & Poor & 6 & 30 \\
\hline $0-44$ & Very Poor & 7 & 35 \\
\hline Total & & 20 & 100 \\
\hline
\end{tabular}


The table above showed that based on the posttest results in the control class 3 people or $15 \%$ of students have abilities with good categories, 4 people or $20 \%$ of students have abilities with sufficient categories, 6 people or $30 \%$ of students have abilities with poor categories, and 7 people or $35 \%$ of students have abilities with very poor categories and there are no students who have abilities with very good categories.

\subsection{Hypothesis Testing}

This part is to do the $\mathrm{t}$ statistic test. The results of the pretest difference test between the experimental group and the control group can be seen in the following table.

Table 5. Differences in the Pretest of the Experimental Group and the Control Group

\begin{tabular}{|c|c|c|c|c|c|}
\hline Group & $\mathrm{N}$ & Average & Difference Average & $\mathrm{T}_{\text {test }}$ & Sig. (2-tailed) \\
\hline Experimental & 20 & 21.00 & -0.50 & -0.130 & 0.897 \\
\hline Control & 20 & 21.50 & & & 0.87 \\
\hline
\end{tabular}

From the t-test in the table above, the t-count value is -0.130 with the value of Sig. (2-tailed) is 0.897 . Because of the value of Sig. (2-tailed) is more than 0.05, it can be concluded that the results of the pretest of the experimental group and the control group have no significant difference. After giving the treatment to each group, the researcher conducted a final test on each group. From the final test data obtained, the difference between the initial test and the final test in the experimental group and the control group can be seen in Table 6 below.

Table 6. Differences in the Post-test of the Experimental Group and the Control Group

\begin{tabular}{|c|c|c|c|c|c|}
\hline Group & $\mathrm{N}$ & Average & Difference Average & $\mathrm{T}_{\text {test }}$ & Sig. (2-tailed) \\
\hline Experimental & 20 & 70.00 & -0.50 & 5.037 & 0.000 \\
\hline Control & 20 & 50.00 & & & \\
\hline
\end{tabular}

The t-test value in the table above shows the t value of 5.037 with a Sig value. (2-tailed) is 0.000 . Because of the value of Sig. (2-tailed) is less than 0.05 , it can be concluded that the posttest results of the experimental group and the control group have significant differences. From the posttest data obtained, the difference between the pretest and posttest in the experimental group can be seen in the following table.

Table 6. Differences in the Experimental Group between Pre-test and Post-test

\begin{tabular}{|c|c|c|c|c|c|}
\hline Group & $\mathrm{N}$ & Average & Difference Average & $\mathrm{T}_{\text {test }}$ & Sig. (2-tailed) \\
\hline Pretest & 20 & 21.00 & $-49,50$ & $-24,956$ & 0.000 \\
\hline Posttest & 20 & 70.00 & & & \\
\hline
\end{tabular}

From the t-test in the table above, the t-count value is $-24,956$ with a Sig value. (2-tailed) is 0.000 . Because of the value of Sig. (2-tailed) is less than 0.05 , it can be concluded that in the experimental group, the results of the pretest and posttest results have significant differences.

\subsection{Factors that Influence the Application of the GTM to Monarch Bali Dalung Students}

The factors that influence the application of the GTM method in learning Japanese, especially learning yobikake outou no hyogen for Monarch Bali Dalung students are as follows. 
1. External Factors

External factors, namely the application of the previous learning method were said to be less attractive. In other words, student learning outcomes had increased and if it had decreased, the method can be said to be less effective to apply. In this study, the application of the previous learning method was said to be less attractive based on the results of the pretest in the control class with the highest score of 40 and the experimental class with the highest score of 40. Learning expressions in Japanese must be in accordance with the meaning and context of using these expressions. Therefore, teachers were required to apply special methods to teach students to understand expressions according to the context. This method was Grammar Translation Method (GTM). The teachers developed students' ability to use Japanese expressions through translations that were in accordance with the context of the proper use of expressions.

2. Internal Factor

The internal factor, in this case, was the motivation of students. Students according to the provisions of RI law no. 20 of 2003 concerning the National Education System is a member of the community who tries to develop their potential through a learning process that is available at certain paths, levels, and types of education. In other words, students are the subject of a lesson. The success of the application of learning methods is influenced by the motivation of students. The success or failure of the application of a method can be seen from the learning outcomes obtained by students. Judging from the results of the questionnaires distributed, $90 \%$ of the students were happy to take lessons in Japanese expressions using the Grammar Translation Method so that it became a motivation for students to learn Japanese expressions.

\section{Conclusion}

Before applying GTM method in the experimental group, the test results of all students had not reached the KKM in the DMM class. The results of the pre-action evaluation showed the lack of students' ability to use yobikake outou no hyogen.

After applying the GTM method, the results of the analysis showed that the average achievement of student learning outcomes was higher than using the ceramah method. The use of the GTM method can improve the learning outcomes of students in DMM2 class, especially in learning the use of the expression yobikake outou no hyogen

The factors that influenced the implementation of the Grammar Translation Method (GTM) were the external factors in the form of applying unattractive methods and internal factors, namely students' learning motivation.

\section{References}

Koizumi, Tamotsu. 1993. Gengogaku Nyumon. Tokyo: Daishuukan

Leech, Geoffrey. 1993. Prinsip-Prinsip Pragmatik. Jakarta : Penerbit Universitas Indonesia (UI-Press)

Levinson, C. Stephen. 1983. Pragmatics. Cambridge : Cambridge University Press

Muneo, Kimura. 1992. Nihongo Kyooiku Hoohooron dalam Nihongo Kyooikugaku. Tokyo : Fukumura Shuppan

Ogawa, Yoshi. 1995. Nihongo Kyouiku Jiten. Tokyo : Taishuukan Shoten Pastika, I Wayan. 2019. Fonetik dan Fonologi: Tata Bunyi Bahasa. Pustaka Larasan. 
Wicaksono, Andri dan Ahmad S. Roza. 2016. Teori Pembelajaran Bahasa (Suatu Catatan Singkat). Yogyakarta : Garudhawaca.

Yule, George. 1996. Pragmatics.England:Oxford University Press 